\title{
Penentuan Kondisi Lingkungan Kerja Fisik yang Optimal Menggunakan Metode Permukaan Respon
}

\author{
Arta Rusidarma Putra ${ }^{1}$ dan, Anggar Guritno ${ }^{2}$ \\ Program Studi Manajemen Fakultas Ekonomi STIE Bina Bangsa, \\ Program Studi Teknik Industri Fakultas Teknik Universitas Islam Indonesia ${ }^{2}$ \\ artar.putra@gmail.com, anggar.guritno@yahoo.com
}

\begin{abstract}
Abstrak -- Banyak akibat yang dapat ditimbulkan oleh kondisi lingkungan kerja yang kurang baik. $\mathrm{Hal}$ tersebut bisa diakibatkan oleh kondisi kebisingan, pencahayaan maupun temperatur. Perlu ditentukan nilai optimal dari faktor lingkungan kerja tersebut guna meningkatkan kinerja operator. Hubungan antara kinerja operator dengan faktor lingkungan kerja seperti kebisingan, pencahayaan dan temperature dapat diketahui dengan mengembangkan model empirik untuk menggambarkan hubungan antara kinerja operator dengan faktor lingkungan kerja tersebut. Model tersebut kemudian digunakan untuk mengoptimalkan kinerja operator. Penelitian ini menggunakan metode permukaan respon. Rancangan percobaan menggunakan rancangan komposit pusat. Penelitian dilakukan dengan cara eksperimen di Laboratorium Analisis Perancangan Kerja dan Ergonomi Universitas Islam Indonesia Yogyakarta. Variabel yang diambil adalah kebisingan, pencahayaan dan temperatur. Range untuk kebisingan adalah 40 dB sampai 75 dB, pencahayaan 200 lux sampai 700 lux, dan temperatur antara $20^{\circ} \mathrm{C}$ sampai $35^{\circ} \mathrm{C}$. Percobaan yang dilakukan adalah pencocokan warna resistor selama 5 menit sesuai dengan kombinasi variabel penelitian yang telah ditentukan dalam metode permukaan respon. Output adalah jumlah kebenaran yang terjadi. Dengan menggunakan model optimasi tersebut diperoleh kondisi lingkungan kerja yang optimal untuk kebisingan sebesar $60.5 \mathrm{~dB}$, pencahayaan 354.5 lux dan temperatur sebesar $25.8^{\circ}$.
\end{abstract}

Kata kunci: Metode Permukaan Respon; Kebisingan; Pencahayaan; dan Temperatur

Abstract -- Many consequences caused by the condition of the work environment is not good. This can be caused by noise, lighting and temperature conditions. We need to determine the optimal value of these work environment factors in order to improve operator performance. The correlation between operator performance with work environment factor such as noise, lighting and temperature are found out by develope empirical model to describe relation between operator performance with work environment factor. The model is used to optimize operator performance. This research use surface response method. The experimental design used a central composite design. The research was conducted by experiments in the Laboratory of Analysis of Work Design and Ergonomics of Islamic University of Indonesia Yogyakarta. Variables taken are noise, lighting and temperature. Range for noise is $40 \mathrm{~dB}$ to $75 \mathrm{~dB}$, lighting 200 lux to 700 lux, and temperatures between $20^{\circ} \mathrm{C}$ to $35^{\circ} \mathrm{C}$. The experiment carried out was the resistor color matching for 5 minutes according to the combination of research variables that have been determined in the surface response method. Output is the number of truths that occur. Using this optimization model, optimal working environment conditions for noise of $60.5 \mathrm{~dB}, 354.5$ lux illumination and temperature of $25.8^{\circ}$.

Keywords: Surface Response Method; Noise; Lighting; and Temperature

\section{PENDAHULUAN}

Suksesnya suatu sistem produksi dalam industri biasanya dinyatakan dalam bentuk besarnya produktivitas atau besarnya rasio output per input yang dihasilkan. Apa, bagaimana, dan dimana pekerjaan diselenggarakan seharusnya merujuk pada konsep pemilihan alternatif metode kerja yang efektif-efisien dan pengaturan lingkungan fisik kerja yang layak.

Dalam keadaan sehat, manusia mampu beradaptasi dengan situasi dan kondisi lingkungan fisik yang bervariasi dalam hal temperatur, kelembaban, getaran, kebisingan, dan lainnya. Akan tetapi lingkungan fisik yang tidak terkendali yang disebabkan kurang diperhatikannya prinsip - prinsip ergonomi akan menimbulkan stres kerja, jika tidak ditanggulangi, akan terus berakumulasi dan secara tiba -tiba bisa menyebabkan hal yang fatal.

Menurut Oesman (2014) kondisi fisik lingkungan kerja dapat menimbulkan bahaya secara langsung maupun tidak langsung bagi 
kesehatan dan keselamatan kerja. Kualitas lingkungan kerja yang rendah secara fisik dan mental dapat menimbulkan tekanan non produktif pada pekerja sehingga banyak muncul kejadian yang mengganggu aktivitas kerja.

Penelitian sejenis tentang lingkungan kerja adalah "Pengukuran Lingkungan Fisik Kerja dan Workstation di Kantor Pos Pusat Samarinda" (Cahyadi \& Kurniawan, 2011). Pada penelitian tersebut dibahas tentang penentuan ruang tunggu dan administrasi pelayanan yang sesuai dengan standar tingkat kenyamanan dan kesehatan serta memiliki layout ruangan yang sesuai dengan kebutuhan kerja. Sedangkan penelitian sebelumnya dengan menggunakan metode Response Surface adalah "Optimaliasi Faktor yang Berpengaruh pada Kualitas Lilin di UD $X$ dengan Metode Response Surface" (Octaviani, Dewi, \& Asrini, 2017). Penelitian tersebut dilakukan pada pembuatan produk lilin untuk mendapatkan desain eksperimen dengan mengkombinasikan faktor dan level agar didapatkan kualitas lilin yang optimum.

Metode Permukaan Respon (response surface methodology) adalah suatu kumpulan dari teknik-teknik statistika dan matematika yang berguna untuk menganalisis permasalahan dengan respon sebagai pusat perhatian dengan dipengaruhi beberapa variabel dan bertujuan mengoptimumkan respon tersebut (Myers, Montgomery, \& Anderson-Cook, 2016). Menurut Bachtiyar \& Amrillah (2011) metode respon permukaan solusi optimum dapat digunakan untuk kondisi minimum, maksimum, kondisi yang paling diinginkan dan kondisi sepanjang batas bawah dan atas.

Kegunaan Metodologi Permukaan Respon dalam suatu eksperimen adalah untuk mengoptimasi respon (variabel output) yang dipengaruhi oleh beberapa variabel terikat (variabel input) (Hadi \& Wahyudi, 2014). Metodologi Permukaan Respon dapat digunakan untuk memprediksi respon yang akan datang dan menentukan nilai dari variabel independen yang mampu mengoptimalkan respon yang di harapkan

Berdasarkan latar belakang di atas, maka akan dibahas berapa kondisi optimal dari lingkungan kerja fisik dengan menerapkan metode response surface sehingga terjadi efisiensi dan efektifitas kerja. Dimana kondisi optimal tersebut diperoleh dari pencarian titik stasioner, yaitu titik yang mengoptimalkan respon. Dalam penelitian ini, dimana akan dilakukan eksperimen tentang pencocokan warna resistor, respon yang dihasilkan akan dimaksimalkan sehingga mendapatkan jumlah kebenaran yang banyak.

\section{METODE PENELITIAN}

Subjek penelitian adalah 10 orang mahasiswa yang telah dilatih sebelumnya. Ada beberapa alat dan fasilitas yang digunakan, seperti ruang iklim sebagai tempat eksperimen yang didalamnya terdapat pencahayaan, kebisingan, dan temperatur yang bisa diatur intensitasnya sesuai kebutuhan. Alat lain yang digunakan adalah lux meter untuk mengetahui berapa intensitas cahaya yang dipancarkan oleh lampu, desibel meter untuk mengetahui tingkat kebisingan, termometer untuk mengetahui suhu ruangan, jam henti (stop watch) untuk mengetahui lamanya pekerjaan, resistor dan PCB, serta alat tulis. Range variabel kebisingan yang digunakan dalam penelitian ini yaitu $40 \mathrm{~dB}$ sampai $75 \mathrm{~dB}$, pencahayaan 200 lux sampai 700 lux, dan temperatur antara $20^{\circ} \mathrm{Csampai} 35^{\circ} \mathrm{C}$. Untuk pencahayaan, range tersebut diambil untuk kategori kerja yang membutuhkan ketelitian, sebagai contoh adalah perakitan sederhana, packing, kerja laboratorium. Sedangkan untuk temperatur, range tersebut diambil karena pada $20^{\circ} \mathrm{C}$ merupakan temperatur yang nyaman untuk bekerja dan $35^{\circ} \mathrm{C}$ merupakan batas toleransi dari temperatur yang tinggi. Untuk kebisingan, peneliti menggunakan range tersebut karena pada level kebisingan $40 \mathrm{~dB}$ merupakan level yang sangat baik untuk konsentrasi sedang pada $75 \mathrm{~dB}$ percakapan menggunakan telepon sulit dilakukan, dan pada percakapan tatap muka harus menaikan volume suara. Perancangan eksperimen yang dilakukan adalah operator melakukan pencocokan warna resistor selama 5 menit sesuai kombinasi variabel yang ditetapkan, hasilnya berupa jumlah kebenaran yang dihasilkan. Data yang telah terkumpul kemudian diolah dengan bantuan software dan manual. Pengolahan data pada penelitian ini terbagi dalam dua tahap perhitungan, yaitu perhitungan untuk uji model regresi dan perhitungan untuk memperoleh nilai maksimal dari variabel.

Analisis hasil perhitungan dan pengolahan data yang digunakan dalam studi kasus ini dilakukan dengan cara melihat nilai simpangan dari model tersebut, apakah terdapat penyimpangan (lack of fit) atau tidak. Bila tidak terdapat penyimpangan (dalam studi kasus ini digunakan taraf $\alpha=5 \%$ ), maka model tersebut dapat diandalkan untuk menerangkan keadaan percobaan (hasil percobaan). Selanjutnya dilakukan uji overall. Uji ini dilakukan apakah semua variabel independent bersama-sama dapat berpengaruh terhadap variabel dependent, atau sebaliknya. Selanjutnya dilakukan uji parsial guna menguji masing-masing koefisiean regresi 
dalam model.

\section{PENGOLAHAN DATA DAN PEMBAHASAN}

Data yang telah terkumpul kemudian diolah dengan bantuan software dan manual. Pengolahan data pada penelitian ini terbagi dalam dua tahap perhitungan, yaitu perhitungan untuk uji model regresi yang meliputi penentuan koefisien persamaan ordo kedua, mencari faktor koreksi, jumlah kuadrat total, jumlah kuadrat regresi, jumlah kuadrat galat, jumlah kuadrat galat murni, jumlah kuadrat simpangan dari model, menghitung kuadrat total regresi, galat simpangan dari model, galat murni, menghitung $F$ hitung regresi dan simpangan dari model, mencari $R^{2}$ serta perhitungan uji lack of fit, uji overall dan uji parsial. Dan juga perhitungan untuk memperoleh nilai maksimasi dari variabel yang meliputi pengkodean, penentuan titik tengah diantara kedua taraf faktor, penentuan hubungan variabel kode dengan variabel asli, penentukan taraf faktor yang bersesuaian dengan nilai $\alpha$, penentuan titik $X_{1}, X_{2}, X_{3}$ yang mengoptimalkan fungsi respons.

Tabel 1. Rerata Hasil Percobaan Tiga Faktor Bersifat Ketelitian Seragam ( $k=3$ )

\begin{tabular}{|lccccc|}
\hline Variabel & \multicolumn{2}{c}{ Simbol } & \multicolumn{3}{c|}{ Range dan level } \\
\hline kebisingan & Asli & Code & $-\mathbf{1}$ & $\mathbf{0}$ & $\mathbf{1}$ \\
\hline pencahayaan & $z_{1}$ & $x_{1}$ & 40 & 57.5 & 75 \\
\hline temperatur & $z_{2}$ & $x_{2}$ & 200 & 450 & 700 \\
\hline & $z_{3}$ & $x_{3}$ & 20 & 27.5 & 35 \\
\hline
\end{tabular}

\begin{tabular}{|c|c|c|c|c|c|c|}
\hline \multicolumn{3}{|c|}{ Variabel Kode } & \multicolumn{3}{|c|}{ Variabel Asli } & \multirow[b]{2}{*}{$\mathrm{Y}$} \\
\hline$X_{1}$ & $\mathrm{X}_{2}$ & $X_{3}$ & $\begin{array}{c}\text { Kebisingan } \\
\text { (desibel) }\end{array}$ & $\begin{array}{c}\text { Pencahayaan } \\
\text { (lux) }\end{array}$ & $\begin{array}{c}\text { Temperatur } \\
\left({ }^{\circ} \mathrm{C}\right)\end{array}$ & \\
\hline-1 & -1 & -1 & 40 & 200 & 20 & 10 \\
\hline-1 & -1 & 1 & 40 & 200 & 35 & 11 \\
\hline-1 & 1 & -1 & 40 & 700 & 20 & 11 \\
\hline-1 & 1 & 1 & 40 & 700 & 35 & 12 \\
\hline 1 & -1 & -1 & 75 & 200 & 20 & 11 \\
\hline 1 & -1 & 1 & 75 & 200 & 35 & 11 \\
\hline 1 & 1 & -1 & 75 & 700 & 20 & 12 \\
\hline 1 & 1 & 1 & 75 & 700 & 35 & 10 \\
\hline 0 & 0 & 0 & 57.5 & 450 & 27.5 & 12 \\
\hline 0 & 0 & 0 & 57.5 & 450 & 27.5 & 13 \\
\hline 0 & 0 & 0 & 57.5 & 450 & 27.5 & 13 \\
\hline 0 & 0 & 0 & 57.5 & 450 & 27.5 & 12 \\
\hline 0 & 0 & 0 & 57.5 & 450 & 27.5 & 12 \\
\hline 0 & 0 & 0 & 57.5 & 450 & 27.5 & 11 \\
\hline-1.682 & 0 & 0 & 28.065 & 450 & 27.5 & 12 \\
\hline 1.682 & 0 & 0 & 86.935 & 450 & 27.5 & 14 \\
\hline 0 & -1.682 & 0 & 57.5 & 29.5 & 27.5 & 6 \\
\hline 0 & 1.682 & 0 & 57.5 & 870.5 & 27.5 & 12 \\
\hline 0 & 0 & -1.682 & 57.5 & 450 & 14.885 & 12 \\
\hline 0 & 0 & 1.682 & 57.5 & 450 & 40.115 & 11 \\
\hline
\end{tabular}




\section{Perhitungan uji model regresi}

Langkah - langkah perhitungan uji model regresi adalah sebagai berikut:

\section{$\frac{\text { Penentuan koefisien persamaan ordo kedua }}{\mathrm{X}}$}

Catatan: $\mathrm{X}_{0}$ bernilai 1, merupakan variabel dummy untuk menduga parameter $\beta_{0}$

$$
\mathrm{X}^{\prime}=\left[\begin{array}{cccccccccccccccccccc}
1 & 1 & 1 & 1 & 1 & 1 & 1 & 1 & 1 & 1 & 1 & 1 & 1 & 1 & 1 & 1 & 1 & 1 & 1 & 1 \\
-1 & -1 & -1 & -1 & 1 & 1 & 1 & 1 & 0 & 0 & 0 & 0 & 0 & 0 & -1.682 & 1.682 & 0 & 0 & 0 & 0 \\
-1 & -1 & 1 & 1 & -1 & -1 & 1 & 1 & 0 & 0 & 0 & 0 & 0 & 0 & 0 & 0 & -1.682 & 1.682 & 0 & 0 \\
-1 & 1 & -1 & 1 & -1 & 1 & -1 & 1 & 0 & 0 & 0 & 0 & 0 & 0 & 0 & 0 & 0 & 0 & -1.682 & 1.682 \\
1 & 1 & 1 & 1 & 1 & 1 & 1 & 1 & 0 & 0 & 0 & 0 & 0 & 0 & 2.829 & 2.829 & 0 & 0 & 0 & 0 \\
1 & 1 & -1 & 1 & 1 & 1 & 1 & 1 & 0 & 0 & 0 & 0 & 0 & 0 & 0 & 0 & 2.829 & 2.829 & 0 & 0 \\
1 & 1 & 1 & 1 & 1 & 1 & 1 & 1 & 0 & 0 & 0 & 0 & 0 & 0 & 0 & 0 & 0 & 0 & 2.829 & 2.829 \\
1 & 1 & -1 & -1 & -1 & -1 & 1 & 1 & 0 & 0 & 0 & 0 & 0 & 0 & 0 & 0 & 0 & 0 & 0 & 0 \\
1 & -1 & 1 & -1 & -1 & 1 & -1 & 1 & 0 & 0 & 0 & 0 & 0 & 0 & 0 & 0 & 0 & 0 & 0 & 0 \\
1 & -1 & -1 & 1 & 1 & -1 & -1 & 1 & 0 & 0 & 0 & 0 & 0 & 0 & 0 & 0 & 0 & 0 & 0 & 0
\end{array}\right]
$$

Matriks serta dapat ditentukan sebagai berikut :

$$
X^{\prime} X=\left[\begin{array}{cccccccccc}
20 & 0 & 0 & 0 & 13.6580 & 13.6580 & 13.6580 & 0 & 0 & 0 \\
0 & 13.6582 & 0 & 0 & 0 & 0 & 0 & 0 & 0 & 0 \\
0 & 0 & 13.6582 & 0 & 0 & 0 & 0 & 0 & 0 & 0 \\
0 & 0 & 0 & 13.6582 & 0 & 0 & 0 & 0 & 0 & 0 \\
13.6580 & 0 & 0 & 0 & 24.0065 & 8 & 8 & 0 & 0 & 0 \\
13.6580 & 0 & 0 & 0 & 8 & 24.0065 & 8 & 0 & 0 & 0 \\
13.6580 & 0 & 0 & 0 & 8 & 8 & 24.0065 & 0 & 0 & 0 \\
0 & 0 & 0 & 0 & 0 & 0 & 0 & 8 & 0 & 0 \\
0 & 0 & 0 & 0 & 0 & 0 & 0 & 0 & 8 & 0 \\
0 & 0 & 0 & 0 & 0 & 0 & 0 & 0 & 0 & 8
\end{array}\right] \quad X^{\prime} \mathrm{Y}=\left[\begin{array}{c}
228 \\
3.36 \\
12.09 \\
-1.68 \\
161.55 \\
138.99 \\
153.06 \\
-2 \\
-4 \\
-2
\end{array}\right]
$$

Langkah selanjutnya yaitu menentukan $\hat{\beta}=\left(\mathrm{X}^{\prime} \mathrm{X}\right)^{-1}\left(\mathrm{X}^{\prime} \mathrm{Y}\right)$, dimana nilai $\left(\mathrm{X}^{\prime} \mathrm{X}\right)^{-1}$ :

$$
\left(X^{\prime} X\right)^{-1}=\left[\begin{array}{cccccccccc}
0.1663 & 0 & 0 & 0 & -0.0568 & -0.0568 & -0.0568 & 0 & 0 & 0 \\
0 & 0.0732 & 0 & 0 & 0 & 0 & 0 & 0 & 0 & 0 \\
0 & 0 & 0.0732 & 0 & 0 & 0 & 0 & 0 & 0 & 0 \\
0 & 0 & 0 & 0.0732 & 0 & 0 & 0 & 0 & 0 & 0 \\
-0.0568 & 0 & 0 & 0 & 0.0694 & 0.0069 & 0.0069 & 0 & 0 & 0 \\
-0.0568 & 0 & 0 & 0 & 0.0069 & 0.0694 & 0.0069 & 0 & 0 & 0 \\
-0.0568 & 0 & 0 & 0 & 0.0069 & 0.0069 & 0.0694 & 0 & 0 & 0 \\
0 & 0 & 0 & 0 & 0 & 0 & 0 & 0.125 & 0 & 0 \\
0 & 0 & 0 & 0 & 0 & 0 & 0 & 0 & 0.125 & 0 \\
0 & 0 & 0 & 0 & 0 & 0 & 0 & 0 & 0 & 0.125
\end{array}\right]
$$


Jadi $\hat{\beta}=\left(\mathrm{X}^{\prime} \mathrm{X}\right)^{-1}\left(\mathrm{X}^{\prime} \mathrm{Y}\right)$ didapat sebesar :

$\left[\begin{array}{l}b_{0} \\ b_{1} \\ b_{2} \\ b_{3} \\ b_{4} \\ b_{5} \\ b_{6} \\ b_{7} \\ b_{8} \\ b_{9}\end{array}\right]=\left[\begin{array}{cccccccccc}0.1663 & 0 & 0 & 0 & -0.0568 & -0.0568 & -0.0568 & 0 & 0 & 0 \\ 0 & 0.0732 & 0 & 0 & 0 & 0 & 0 & 0 & 0 & 0 \\ 0 & 0 & 0.0732 & 0 & 0 & 0 & 0 & 0 & 0 & 0 \\ 0 & 0 & 0 & 0.0732 & 0 & 0 & 0 & 0 & 0 & 0 \\ -0.0568 & 0 & 0 & 0 & 0.0694 & 0.0069 & 0.0069 & 0 & 0 & 0 \\ -0.0568 & 0 & 0 & 0 & 0.0069 & 0.0694 & 0.0069 & 0 & 0 & 0 \\ -0.0568 & 0 & 0 & 0 & 0.0069 & 0.0069 & 0.0694 & 0 & 0 & 0 \\ 0 & 0 & 0 & 0 & 0 & 0 & 0 & 0.125 & 0 & 0 \\ 0 & 0 & 0 & 0 & 0 & 0 & 0 & 0 & 0.125 & 0 \\ 0 & 0 & 0 & 0 & 0 & 0 & 0 & 0 & 0 & 0.125\end{array}\right] \times\left[\begin{array}{c}228 \\ 3.36 \\ 12.09 \\ -1.68 \\ 161.55 \\ 138.99 \\ 153.06 \\ -2 \\ -4 \\ -2\end{array}\right]=\left[\begin{array}{c}12.17 \\ 0.246 \\ 0.885 \\ -0.123 \\ 0.272 \\ -1.141 \\ -0.258 \\ -0.25 \\ -0.5 \\ -0.25\end{array}\right]$

Dengan demikian persamaan respons ordo kedua dapat diduga sebagai berikut :

$\hat{Y}=12.17+0.246 X_{1}+0.885 X_{2}-0.123 X^{3}+0.272 X_{1}^{2}-1.142 X_{2}^{2}-0.258 X_{3}^{2}-0.25 X_{1} X_{2}-$ $0.5 X_{1} X_{3}-0.25 X_{2} X_{3}$

persamaan 1

\section{Penentuan faktor koreksi}

Faktor Koreksi $(\mathrm{FK})=\frac{\left(\sum \mathrm{Y}\right)^{2}}{n}=\frac{(228)^{2}}{20}=2599.2$

\section{Penentuan Jumlah Kuadrat Total (JKT)}

Jumlah Kuadrat Total $(\mathrm{JKT})=\sum \mathrm{Y}^{2}-F K=2648-2599.2=48.8$

dengan derajat bebas $(\mathrm{db})$ total $=n-1=20-1=19$

Penentuan Jumlah Kuadrat Regresi (JKR)

Jumlah Kuadrat Regresi (JKR)

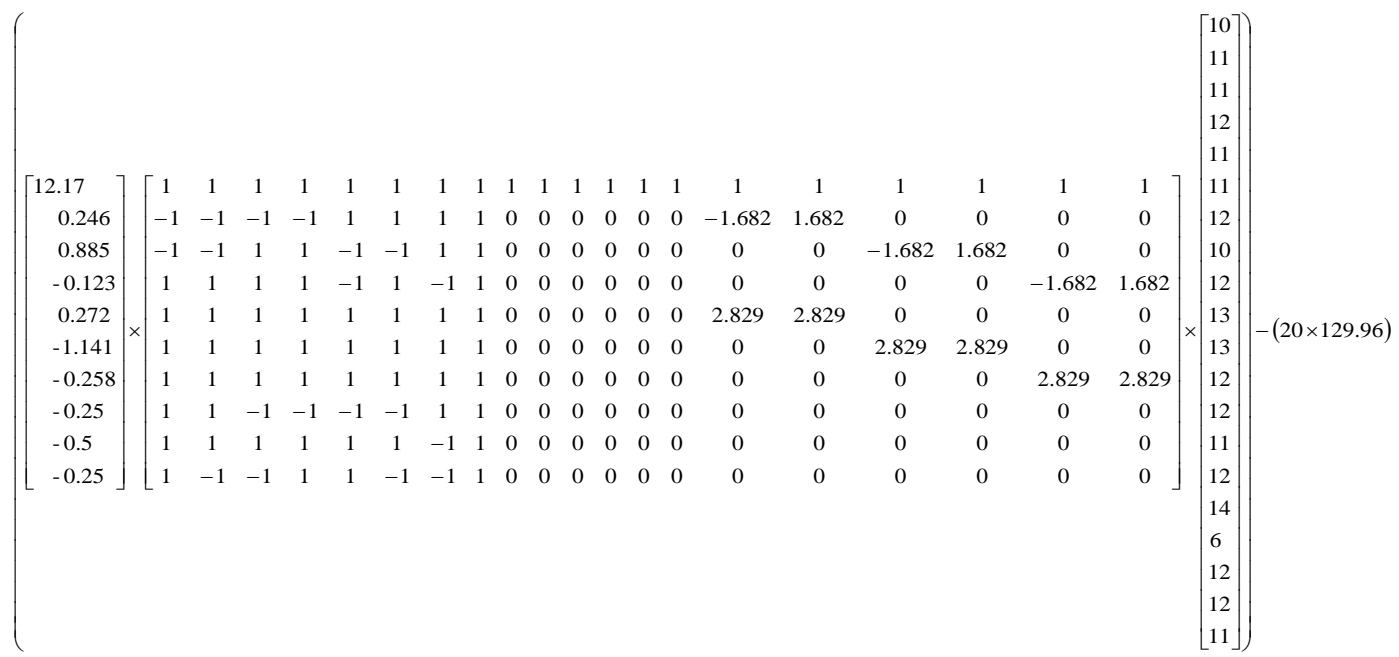

Dengan demikian $J K R=2635.4-(20)(129.96)=36.2$

dengan derajat bebas $(\mathrm{db})$ regresi $=k-1=10-1=9$ 
Perhitungan Penentuan Jumlah Kuadrat Galat (JKG)

Jumlah Kuadrat Galat $(J K G)=J K T-J K R=48.8-36.2=12.6$

dengan derajat bebas ( $d b)$ galat $=d b$ total $-d b$ regres $i=19-9=10$

Perhitungan Jumlah Kuadrat Galat Murni (JKGM)

Jumlah Kuadrat Galat Murni $(J K G M)=\left(\sum Y^{2}-\frac{\left(\sum Y\right)^{2}}{n}\right)=\left(891-\frac{5329}{6}\right)=2.833$

dengan derajat bebas (db) galat murni = banyaknya ulangan pada $\mathrm{X}_{1}, \mathrm{X}_{2}, \mathrm{X}_{3}(0,0,0)$ dikurangi $1=6-1=5$

Penentuan Jumlah Kuadrat Simpangan dari Model (JKSDM)

Jumlah Kuadrat Simpangan dari Model (JKSDM) = JKG - JKGM $=12.6-2.833=9.767$

derajat bebas ( $d b)$ simpangan dari model $=d b$ galat $-d b$ galat murni $=10-5=5$

Kuadrat Total (KT) Regresi $=\frac{J K R}{d b \operatorname{Re} \text { gresi }}=\frac{36.2}{9}=4.02$

Kuadrat Total (KT) Galat $=\frac{J K G}{d b \text { Galat }}=\frac{12.6}{10}=1.26$

Kuadrat Total (KT) SDM $=\frac{J K S D M}{d b S D M}=\frac{9.767}{5}=1.953$

Kuadrat Total (KT) GM $=\frac{J K G M}{d b G M}=\frac{2.833}{5}=0.567$

$\mathrm{F}$ hitung regresi $=\frac{\text { KTregres } i}{\text { KTgalat }}=\frac{4.02}{1.26}=3.19$

F hitung SDM $=\frac{K T S D M}{K T G M}=\frac{1.9533}{0.5667}=3.45$

Perhitungan $R^{2}=\frac{J K T}{J K R}=\frac{48.8}{36.2}=1.348$

\section{Uji Lack Of Fit (penyimpangan dari model)}

Hipotesis : Ho: Tidak ada Lack of Fit; $\mathrm{H}^{1}$ : Ada Lack of Fit

Tingkat signifikasi: $\alpha=0.05 \quad d f_{1}=5 \quad d f_{2}=5 \quad \mathrm{~F}_{\text {tabel }}=5.05$

Daerah kritis: Bila $F_{\text {hitung }}>F_{\text {tabel }}$ maka Ho ditolak; Bila $F_{\text {hitung }}<F_{\text {tabel }}$ maka Ho ditrima

Statistik Uji : $\mathrm{F}_{\text {hitung }}=\frac{1.9533}{0.5667}=3.45$

Kesimpulan: Karena $F_{\text {hitung }}<F_{\text {tabel }}$ yaitu $3.45<5.05$ maka Ho diterima yang berarti tidak ada lack of fit ( tidak ada penyimpangan dari model).

\section{Uji Overall ( Uji Regresi )}

Hipotesis :

Ho: Semua variabel independent tidak mempengaruhi variabel dependent

$\mathrm{H}^{1}$ : Minimal ada satu variabel independent yang mempengaruhi variabel

Tingkat signifikasi: $\alpha=0.05 \quad d f_{1}=9 \quad d f_{2}=10 \quad \mathrm{~F}_{\text {tabel }}=3.02$

Daerah kritis: Bila $F_{\text {hitung }}>F_{\text {tabel }}$ maka Ho ditolak; Bila $F_{\text {hitung }}<F_{\text {tabel }}$ maka Ho diterima 
Statistik Uji : $\mathrm{F}_{\text {hitung }}=\frac{4.02}{1.26}=3.19$

\section{Kesimpulan:}

Karena $F_{\text {hitung }}>F_{\text {tabel }}$ yaitu $3.19<3.02$ maka Ho ditolak yang berarti minimal ada satu variabel independent yang mempengaruhi variabel

\section{Uji Parsial}

1. Pengujian koefisien regresi prediktor kebisingan $\left(b^{1}\right)$

Hipotesis : Ho: $\mathrm{b}_{1}=0 ; \mathrm{H}^{1}: \mathrm{b}_{1} \neq 0$

Tingkat signifikasi: $\alpha=0.05 \quad d f=n-2=20-2=18 \quad \mathrm{t}_{\alpha / 2}=2.101$

Daerah kritis: Bila $-t_{\alpha / 2} \leq t_{\text {hitung }} \leq t_{\alpha / 2}$ maka Ho diterima; Bila $t_{\text {hitung }}<-t_{\alpha / 2}$ atau $t_{\text {hitung }}>t_{\alpha / 2}$ maka Ho ditolak

Perhitungan : $\mathrm{t}_{\text {hitung }}=\frac{\text { koefisien }}{\text { SE_koefisien }}=\frac{0.246}{0.3041}=0.808$

Kesimpulan: Ho diterima

2. Pengujian koefisien regresi prediktor pencahayaan $\left(b_{2}\right)$

Hipotesis : $\mathrm{Ho} \mathrm{b}_{2}=0 ; \mathrm{H}^{1}: \mathrm{b}_{2} \neq 0$

Tingkat signifikasi: $\alpha=0.05 \quad d f=n-2=18 \quad \mathrm{t}_{\alpha / 2}=2.101$

Daerah kritis: Bila $-t_{\alpha / 2} \leq t_{\text {hitung }} \leq t_{\alpha / 2}$ maka Ho diterima; Bila $t_{\text {hitung }}<-t_{\alpha / 2}$ atau $t_{\text {hitung }}>t_{\alpha / 2}$ maka Ho ditolak

Statistik Uji : $\mathrm{t}_{\text {hitung }}=\frac{\text { koefisien }}{\text { SE_koefisien }}=\frac{0.885}{0.3041}=2.911$

Kesimpulan: Ho ditolak

3. Pengujian koefisien regresi prediktor temperatur $\left(b_{3}\right)$

Hipotesis : Ho: $\mathrm{b}_{3}=0 ; \mathrm{H}^{1}: \mathrm{b}_{3} \neq 0$

Tingkat signifikasi: $\alpha=0.05 \quad d f=n-2=18 \quad \mathrm{t}_{\alpha / 2}=2.101$

Daerah kritis: Bila $-t_{\alpha / 2} \leq t_{\text {hitung }} \leq t_{\alpha / 2}$ maka Ho diterima; Bila $t_{\text {hitung }}<-t_{\alpha / 2}$ atau $t_{\text {hitung }}>t_{\alpha / 2}$ maka Ho ditolak

Statistik Uji : $\mathrm{t}_{\text {hitung }}=\frac{\text { koefisien }}{\text { SE_koefisien }}=\frac{-0.123}{0.3041}=-0.405$

Kesimpulan: Ho diterima

4. Pengujian koefisien regresi prediktor kebisingan*kebisingan $\left(\mathrm{b}_{4}\right)$

Hipotesis : Ho: ${ }^{b_{4}=0} ; \mathrm{H}^{1}: \mathrm{b}_{4} \neq 0$

Tingkat signifikasi: $\alpha=0.05 \quad d f=n-2=18 \quad \mathrm{t}_{\alpha / 2}=2.101$

Daerah kritis: Bila $-t_{\alpha / 2} \leq t_{\text {hitung }} \leq t_{\alpha / 2}$ maka Ho diterima; Bila $t_{\text {hitung }}<-t_{\alpha / 2}$ atau $t_{\text {hitung }}>t_{\alpha / 2}$ maka Ho ditolak

Statistik Uji : $\mathrm{t}_{\text {hitung }}=\frac{\text { koefisien }}{\text { SE_koefisien }}=\frac{0,272}{0.2960}=0.920$ 
Kesimpulan: Ho diterima

5. Pengujian koefisien regresi prediktor pencahayaan* pencahayaan $\left(b_{5}\right)$

Hipotesis : Ho: $\mathrm{b}_{5}=0 ; \mathrm{H}^{1}: \mathrm{b}_{5} \neq 0$

Tingkat signifikasi: $\alpha=0.05 \quad d f=n-2=18 \quad \mathrm{t}_{\alpha / 2}=2.101$

Daerah kritis: Bila $-t_{\alpha / 2} \leq t_{\text {hitung }} \leq t_{\alpha / 2}$ maka Ho diterima; Bila $t_{\text {hitung }}<-t_{\alpha / 2}$ atau $t_{\text {hitung }}>t_{\alpha / 2}$ maka Ho ditolak

Statistik Uji : $\mathrm{t}_{\text {hitung }}=\frac{\text { koefisien }}{\text { SE_koefisien }}=\frac{-1.142}{0.2960}=-3.858$

Kesimpulan: Ho ditolak

6. Pengujian koefisien regresi prediktor temperatur*temperatur $\left(b_{6}\right)$

Hipotesis : Ho: $\mathrm{b}_{6}=0 ; \mathrm{H}^{1}: \mathrm{b}_{6} \neq 0$

Tingkat signifikasi: $\alpha=0.05 \quad d f=n-2=18 \quad \mathrm{t}_{\alpha / 2}=2.101$

Daerah kritis: Bila $-t_{\alpha / 2} \leq t_{\text {hitung }} \leq t_{\alpha / 2}$ maka Ho diterima; Bila $t_{\text {hitung }}<-t_{\alpha / 2}$ atau $t_{\text {hitung }}>t_{\alpha / 2}$ maka Ho ditolak

Statistik Uji : $\mathrm{t}_{\text {hitung }}=\frac{\text { koefisien }}{S E_{\text {k }} \text { oefisien }}=\frac{-0.258}{0.2960}=-0.872$

Kesimpulan: Ho diterima

7. Pengujian koefisien regresi prediktor kebisingan*pencahayaan $\left(b_{7}\right)$

Hipotesis : $\mathrm{Ho}: \mathrm{b}_{7}=0 ; \mathrm{H}^{1}: \mathrm{b}_{7} \neq 0$

Tingkat signifikasi: $\alpha=0.05 \quad d f=n-2=18 \quad \mathrm{t}_{\alpha / 2}=2.101$

Daerah kritis: Bila $-t_{\alpha / 2} \leq t_{\text {hitung }} \leq t_{\alpha / 2}$ maka Ho diterima; Bila $t_{\text {hitung }}<-t_{\alpha / 2}$ atau $t_{\text {hitung }}>t_{\alpha / 2}$ maka Ho ditolak

Statistik Uji : $\mathrm{t}_{\text {hitung }}=\frac{\text { koefisien }}{S E_{\text {k }} \text { oefisien }}=\frac{-0.250}{0.3973}=-0.629$

Kesimpulan: Ho diterima

8. Pengujian koefisien regresi prediktor kebisingan*temperatur $\left(b_{8}\right)$

Hipotesis : $\mathrm{Ho}: \mathrm{b}_{8}=0 ; \mathrm{H}^{1}: \mathrm{b}_{8} \neq 0$

Tingkat signifikasi: $\alpha=0.05 \quad d f=n-2=18 \quad \mathrm{t}_{\alpha / 2}=2.101$

Daerah kritis: Bila $-t_{\alpha / 2} \leq t_{\text {hitung }} \leq t_{\alpha / 2}$ maka Ho diterima; Bila $t_{\text {hitung }}<-t_{\alpha / 2}$ atau $t_{\text {hitung }}>t_{\alpha / 2}$ maka Ho ditolak

Statistik Uji : $\mathrm{t}_{\text {hitung }}=\frac{\text { koefisien }}{\text { SE_koefisien }}=\frac{-0.500}{0.3973}=-1.258$

Kesimpulan: Ho diterima

9. Pengujian koefisien regresi prediktor pencahayaan ${ }^{*}$ temperatur $\left({ }^{b_{9}}\right)$ 
Hipotesis : Ho: $\mathrm{b}_{9}=0 ; \mathrm{H}^{1}: \mathrm{b}_{8} \neq 0$

Tingkat signifikasi: $\alpha=0.05 \quad d f=n-2=18 \quad \mathrm{t}_{\alpha / 2}=2.101$

Daerah kritis: Bila $-t_{\alpha / 2} \leq t_{\text {hitung }} \leq t_{\alpha / 2}$ maka Ho diterima; Bila $t_{\text {hitung }}<-t_{\alpha / 2}$ atau $t_{\text {hitung }}>t_{\alpha / 2}$ maka Ho ditolak

Statistik Uji : $\mathrm{t}_{\text {hitung }}=\frac{\text { koefisien }}{\text { SE_koefisien }}=\frac{-0.250}{0.3973}=-0.629$

Kesimpulan: Ho diterima

\section{Perhitungan untuk memperoleh nilai maksimasi dari variabel}

\section{Penentuan taraf faktor (pemberian kode untuk masing-masing faktor)}

Faktor kebisingan (K): 40 desibel (kode $\mathrm{X}_{1}=-1$ ) dan 75 desibel (kode $\mathrm{X}_{1}=1$ )

Faktor pencahayaan $(P): 200$ lux (kode $X_{2}=-1$ ) dan 700 lux (kode $X_{2}=1$ )

Faktor temperatur (T) : $20^{\circ} \mathrm{C}$ (kode $\left.\mathrm{X}_{3}=-1\right)$ dan $35^{\circ} \mathrm{C}$ (kode $\mathrm{X}_{3}=1$ )

\section{Penentuan taraf faktor yang bersesuaian dengan titik pusat}

Faktor kebisingan $(\mathrm{K})$ dengan titik pusat : $\frac{40+75}{2}=57.5\left(\right.$ kode $\mathrm{X}_{1}=0$ )

Faktor pencahayaan $(P)$ dengan titik pusat : $\frac{200+700}{2}=450\left(\right.$ kode $\left.X_{2}=0\right)$

Faktor temperatur $(\mathrm{T})$ dengan titik pusat : $\frac{20+35}{2}=27.5\left(\right.$ kode $\left.\mathrm{X}_{3}=0\right)$

$\underline{\text { Penentuan hubungan antara variabel kode }} \mathrm{X}_{1}, \mathrm{X}_{2}, \mathrm{X}_{3}$ dan variabel asli

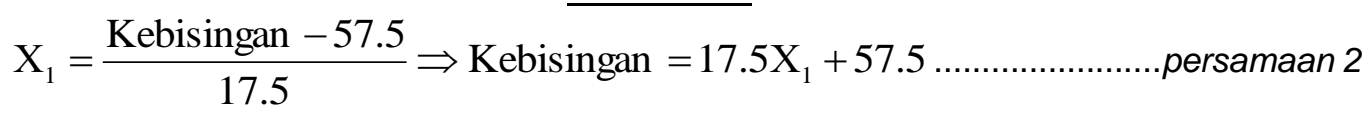

$\mathrm{X}_{2}=\frac{\text { Pencahay aan }-450}{250} \Rightarrow$ Pencahay aan $=250 \mathrm{X}_{2}+450 \ldots \ldots \ldots \ldots \ldots \ldots$ persamaan 3

$\mathrm{X}_{3}=\frac{\text { Temperatur }-27.5}{7.5} \Rightarrow$ Temperatur $=7.5 \mathrm{X}_{3}+27.5 \ldots \ldots \ldots \ldots \ldots \ldots \ldots$ persamaan 4

\section{$\underline{\text { Penentuan taraf faktor yang bersesuaian dengan nilai-nilai } \alpha}$}

Untuk $\mathrm{X}_{1}=-1.68$, maka $K=17.5(-1.68)+27.5=28.068$

Untuk $\mathrm{X}_{1}=1.68$, maka $K=17.5(1.68)+27.5=86.935$

Untuk $\mathrm{X}_{2}=-1.68$, maka $P=250(-1.68)+450=29.5$

Untuk $\mathrm{X}_{2}=1.68$, maka $P=250(1.68)+450=870.5$

Untuk $\mathrm{X}_{3}=-1.68$, maka $T=7.5(-1.68)+27.5=14.885$

Untuk $X_{3}=1.68$, maka $T=7.5(1.68)+27.5=40.115$ 
Penentuan titik $\mathrm{X}_{1}, \mathrm{X}_{2}, \mathrm{X}_{3}$ yang mengoptimalkan fungsi respons

a. Syarat perlu

Dari persamaan 4.1 apabila didiferensiasikan untuk memenuhi syarat perlu, maka akan diperoleh hasil berupa sistem persamaan linear sebagai berikut :
1)
$0.544 \mathrm{X}_{1}-0.25 \mathrm{X}_{2}-0.25 \mathrm{X}_{3}=0.246$
2)
$-0.25 X_{1}-2.282 X_{2}-0.25 X_{3}=0.885$
3)
$-0.5 X_{1}-0.25 X_{2}-0.516 X_{3}=-0.123$

Perhitungan persamaan di atas :

1) $\quad 0.544 X_{1}-0.25 X_{2}-0.25 X_{3}=0.246$

2) $\begin{array}{r}-0.25 X_{1}-2.282 X_{2}-0.25 X_{3}=0.885 \\ \hline 0.794 X_{1}+2.032 X_{2}=-0.639\end{array}$ persamaan a
1) $\quad 0.544 X_{1}-0.25 X_{2}-0.25 X_{3}=0.246$
3) $\quad-0.5 X_{1}-0.25 X_{2}-0.516 X_{3}=-0.123$
$0.281 X_{1}-0.129 X_{2}-0.129 X_{3}=0.127$
$\frac{-0.125 X_{1}-0.0625 X_{2}-0.129 X_{3}=0.03075}{0.406 X_{1}-0.0665 X_{2}}-$ persamaan $b$

Dari hasil persamaan regresi dengan mengeliminasikan konstanta $X_{3}$ kemudian dilakukan proses eliminasi yang kedua, misalkan $\mathrm{X}_{1}$ di nol-kan :

$$
\begin{aligned}
& \text { persamaan a } \\
& 0.794 X_{1}+2.032 X_{2}=-0.639 \\
& \text { persamaan } b \\
& 0.406 X_{1}-0.0665 X_{2}=0.09625 \quad(\times 0.794) \\
& 0.322 \mathrm{X}_{1}+0.825 \mathrm{X}_{2}=-0.259 \\
& \begin{aligned}
0.322 X_{1}-0.0528 X_{2} & =0.0764 \\
\hline 0.8778 X_{2} & =-0.3354
\end{aligned} \\
& X_{2}=-0.382
\end{aligned}
$$

Dari persamaan di atas diperoleh titik stasioner

$X_{1}=-0.382$

$X_{2}=0.172$

$X_{3}=-0.2276$

\section{b. Syarat cukup}

Berikutnya perlu diperiksa apakah titik stasioner itu bersifat maksimum dengan jalan memeriksa syarat cukup. Dari persamaan regresi 1 juga dapat diturunkan matriks Hessian, $\mathrm{H}$, sebagai berikut :

$\mathrm{H}=\left[\begin{array}{ccc}0.544 & -0.25 & -0.25 \\ -0.25 & -2.282 & -0.25 \\ -0.5 & -0.25 & -0.516\end{array}\right]$

Dari matriks $\mathrm{H}$ dapat ditentukan nilai-nilai determinan minor utama yaitu : 


$$
\begin{aligned}
& \mathrm{D}_{1}=0.544 \\
& \mathrm{D}_{2}=(0.544)(-2.282)-(-0.25)(-0.25)=-1.3035 \\
& \mathrm{D}_{3}=\operatorname{Det}|\mathrm{H}|=0.8883
\end{aligned}
$$

Berdasarkan persamaan 2, 3 dan 4, maka dapat kita tentukan nilai-nilai kebisingan, pencahayaan dan temperatur berdasarkan nilai-nilai titik stasioner yang diperoleh, dimana :

$$
\begin{array}{lll}
\text { Kebisingan }=17.5 \mathrm{X}_{1}+57.5 & \rightarrow & 17.5(-0.382)+57.5=60.51 \\
\text { Pencahay aan }=250 \mathrm{X}_{2}+450 & \rightarrow & 250(0.172)+450=354.5 \\
\text { Temperatur }=7.5 \mathrm{X}_{3}+27.5 & \rightarrow & 7.5(-0.2276)+27.5=25.793
\end{array}
$$

\begin{tabular}{|c|c|c|c|c|c|}
\hline Sumber Keragaman & DB & JK & KT & $\mathbf{F}_{\text {hitung }}$ & $\mathbf{F}_{\text {tabel (5\%) }}$ \\
\hline Regresi & 9 & 36.2 & 4.02 & 3.19 & 3.02 \\
\hline Galat & 10 & 12.6 & 1.26 & & \\
\hline - SDM & 5 & 9.767 & 1.953 & 3.45 & 5.05 \\
\hline - $\quad$ GM & 5 & 2.833 & 0.567 & & \\
\hline Total & 19 & $\begin{array}{l}48.8 \\
\end{array}$ & & & \\
\hline
\end{tabular}

Jadi, dari perhitungan di atas dapat ditarik kesimpulan untuk pengolahan data ini seperti terlihat dalam tabel di bawah ini :

Tabel 2. Daftar Analisis Ragam Pengujian Ketepatan Model Ordo Kedua

Tabel 3. Hasil Pengolahan Data

\begin{tabular}{|l|l|c|c|}
\hline Titik Stasioner & \multicolumn{2}{|c|}{ Persamaan } & Nilai Maksimal \\
\hline $\mathrm{X}_{1}=-0.382$ & Kebisingan & $17.5 \mathrm{X}_{1}+57.5$ & 60.51 \\
\hline $\mathrm{X}_{2}=0.172$ & Pencahayaan & $250 \mathrm{X}_{2}+450$ & 354.5 \\
\hline $\mathrm{X}_{3}=-0.2276$ & Temperatur & $7.5 \mathrm{X}_{3}+27.5$ & 25.793 \\
\hline
\end{tabular}

\section{KESIMPULAN}

Berdasarkan hasil analisis dan pembahasan yang dilakukan, maka dalam penelitian ini dapat disimpulkan bahwa titik stasioner yang memaksimumkan respons (banyaknya kebenaran yang terjasi) yang didapat dari hasil pengolahan data adalah $\mathrm{X}_{1}=-0.382$, $\mathrm{X}_{2}=0.172$ dan $\mathrm{X}_{3}=-0.2276$, titik stasioner didapat nilai kebisingan sebesar $60.51 \mathrm{~dB}$, sedangkan pencahayaan sebesar 354.5 lux dan temperatur sebesar $25.793^{\circ} \mathrm{C}$ dengan respon maksimum yang diduga untuk hasil output adalah sebesar 12. Pada penelitian ini variabel yang paling berpengaruh terhadap kerja operator adalah pencahayaan dengan nilai koefisien sebesar 0.885 .

\section{DAFTAR PUSTAKA}

Bachtiyar, C., \& Amrillah, R. (2011). Setting Parameter Mesin Press Dengan Metode Respon Permukaan pada Pabrik Kelapa
Sawit. Jurnal Riset Industri, V(2), 153-160.

Cahyadi, D., \& Kurniawan, A. (2011). Pengukuran Lingkungan Fisik Kerja Dan Workstation Di Kantor Pos Pusat Samarinda. Jurnal Eksis, 7(2), 1931-1938.

Hadi, Y., \& Wahyudi, S. (2014). Aplikasi Metode Objective Matrix dan Response Surface Methodology. Jemis, 2(1), 26-33.

Myers, R. H., Montgomery, D. C., \& AndersonCook, C. M. (2016). Response Surface Methodology: Process and Product Optimization Using Designed Experiments. John Wiley \& Sons. New Jersey.

Octaviani, M. A., Dewi, D. R. S., \& Asrini, L. J. (2017). Optimaliasi Faktor yang Berpengaruh pada Kualitas Lilin di UD $X$ dengan Metode Response Surface. Jurnal IImiah Widya Teknik, 26(1), 29-38.

Oesman, T. I. (2014). Evaluasi Kondisi Lingkungan Kerja Pada Bagian Proses Pengecoran $\mathrm{Di}$ Industri Kerajinan Cor Alumunium " Ed " Jogjakarta. INASEA 15(1), 71-78. 